\title{
BEBERAPA FAKTOR PENYEBAB GANGGUAN FAAL PARU PADA PENJUAL UNGGAS DI PASAR BURUNG KUPANG SURABAYA
}

\author{
Fariz Zuvil Arganata \\ PT. Charoen Pokphand Indo-Food Division \\ Jl. Industri IV Modern Industri Estate Kav. 6-8 Desa Nambo Ilir - Cikande, Serang \\ Email: fariz.arganata@gmail.com
}

\begin{abstract}
Poultry sellers is one of the jobs potentially impaired pulmonary function. Impaired pulmonary function status of workers caused by external factors and internal factors. The aim of this research was to identify factors which cause impaired pulmonary function the poultry sellers in bird market in Kupang Surabaya. This research used cross sectional design. Data obtained by the measurements, examination and questionnaire. The sample of this research is 20 respondents which drawn from $10 \%$ of the total population. Data were analyzed by cross tabulation. The measurements result of dust levels, $\mathrm{SO}_{2}, \mathrm{NO}_{2}, \mathrm{NH}_{3}$ and $\mathrm{H}_{2} \mathrm{~S}$ respectively $0.3848 \mathrm{mg} / \mathrm{m} 3,0.0047 \mathrm{mg} / \mathrm{m} 3,0.0207 \mathrm{ppm}, 0.0638 \mathrm{ppm}, 0.0002$ ppm were below the TLV. Pulmonary function test results of 20 respondents, there were 13 (65\%) of respondents have normal status of pulmonary function and 7 (35\%) of respondents impaired pulmonary function with details of 4 (20\%) of respondents mild obstruction, 1 (5\%) of respondents restriction mild and 2 (10\%) of respondents mixture. The conclusion of this study are the pulmonary status of respondents in Surabaya Kupang bird market not affected by external factors such as exposure to gas and dust, but affected by internal factors such as age, years of service, and years of smoking history. There is no association between the nutritional status of respondents with pulmonary function status. Respondents should reduce cigarette consumption and conduct regular health checks.
\end{abstract}

Keywords: pulmonary function status, sellers poultry, bird market

\begin{abstract}
ABSTRAK
Penjual unggas merupakan salah satu pekerjaan yang berpotensi mengalami gangguan faal paru. Gangguan faal paru dapat disebabkan oleh faktor eksternal dan faktor internal. Penelitian ini bertujuan untuk mengidentifikasi faktor-faktor yang dapat menyebabkan gangguan faal paru pada penjual unggas yang ada di pasar burung kupang, Surabaya. Penelitian menggunakan rancangan cross sectional. Pengumpulan data dilakukan dengan cara melakukan pengukuran, pemeriksaan dan kuesioner. Sampel penelitian adalah 20 responden yang diambil dari 10\% total populasi. Analisis data menggunakan metode crosstab. Hasil pengukuran kadar debu sebesar $0,3848 \mathrm{mg} / \mathrm{m}^{3}$, konsentrasi $\mathrm{SO}_{2}$ sebesar $0,0047 \mathrm{mg} / \mathrm{m}^{3}, \mathrm{NO}_{2}$ sebesar $0,0207 \mathrm{ppm}, \mathrm{NH}_{3}$ sebesar 0,0638 ppm dan $\mathrm{H}_{2} \mathrm{~S}$ sebesar 0,0002 ppm. Hasil pemeriksaan faal paru dari 20 responden, 13 $(65 \%)$ responden memiliki status faal paru normal dan 7 (35\%) responden mengalami gangguan faal paru dengan rincian $4(20 \%)$ responden obstruksi ringan, $1(5 \%)$ responden restriksi ringan, dan $2(10 \%)$ responden campuran. Kesimpulan dari penelitian ini adalah sebagian besar responden memiliki status faal paru normal. Faktor eksternal berupa paparan gas dan debu masih di bawah NAB, namun ada faktor lain berupa faktor internal yaitu umur, masa kerja, dan riwayat merokok yang memiliki kecenderungan menyebabkan gangguan faal paru responden. Sebaiknya responden membersihkan kandang unggas setiap hari, mengurangi konsumsi rokok dan melakukan pemeriksaan kesehatan secara berkala.
\end{abstract}

Kata kunci: status faal paru, penjual unggas, pasar burung

\section{PENDAHULUAN}

Semakin banyaknya pecinta burung membuat pasar burung tidak pernah sepi pengunjung. Permintaan akan burung yang terus meningkat merupakan peluang bisnis yang bagus bagi para penjual unggas maupun orang baru yang ingin memulai menekuni bisnis ini. Pasar burung tidak hanya menjual burung melainkan segala macam unggas, pakan unggas, dan hewan-hewan peliharaan lainnya. Hal ini tentu memberikan dampak positif bagi perekonomian masyarakat karena bisa dijadikan sebagai lahan bisnis yang menjanjikan, namun juga bisa menimbulkan dampak negatif bagi penjualnya. Salah satu dampak negatifnya adalah banyaknya polutan partikel dan pencemaran udara berupa bau yang tidak enak dan menyengat yang disebabkan oleh kandungan amonia yang tinggi pada feses unggas.

Amonia adalah gas yang memiliki bau tajam yang khas. Amonia juga termasuk dalam senyawa 
kaustik dan dapat merusak kesehatan. Amonia dapat berwujud cair dan terlarut dengan feses dalam bentuk $\left(\mathrm{NH}_{4} \mathrm{OH}\right)$ dan dalam bentuk gas $\left(\mathrm{NH}_{3}\right)$. Menurut Administrasi Keselamatan dan Kesehatan Pekerjaan Amerika Serikat batas waktu kontak dengan amonia dalam gas berkonsentrasi $35 \mathrm{ppm}$ volume adalah 15 menit atau 8 jam untuk $25 \mathrm{ppm}$ volume. Terpapar gas amonia dengan konsentrasi tinggi dapat menyebabkan kerusakan paru, sedangkan paparan amonia pada kadar rendah secara kronik dapat mengakibatkan gangguan paru berupa gangguan restriktif, yang merupakan suatu indikasi adanya penyakit paru (encyclopedia).

Polutan partikel masuk ke dalam tubuh manusia terutama melalui sistem pernafasan, oleh karena itu pengaruh yang merugikan terutama terjadi pada sistem pernafasan. Perjalanan debu yang masuk ke saluran pernafasan dipengaruhi oleh ukuran partikel tersebut. Debu dengan ukuran 5-10 $\mu \mathrm{m}$ atau lebih akan mengendap di jalan pernafasan bagian atas dan debu dengan ukuran 2-4 $\mu \mathrm{m}$ mengendap di jalan pernafasan bagian tengah, sedangkan debu berukuran $0,5 \mu \mathrm{m}$ tidak sampai mengendap di saluran pernafasan akan tetapi dikeluarkan lagi (Amin, 1996).

Debu yang terhirup ke dalam saluran pernafasan dapat mengakibatkan terjadinya kerusakan jaringan setempat dari yang ringan sampai kerusakan yang parah dan menetap. Derajat kerusakan yang ditimbulkan oleh debu dapat dipengaruhi oleh asal dan sifat alamiah debu, jumlah debu yang masuk dan lamanya pemaparan, dan reaksi imunologis subjek yang terkena paparan. Suma'mur (2009), mengelompokkan partikel debu menjadi dua yaitu debu organik dan anorganik.

Sebesar $80 \%$ pencemaran udara di daerah perkotaan di Indonesia disumbang oleh sektor transportasi. NO merupakan salah satu dari pencemaran udara yang berasal dari kendaraan bermotor (Mukono, 1997). Pengukuran yang dilakukan pada tahun 2007 menunjukkan bahwa konsentrasi debu di beberapa lokasi masih melebihi batas baku mutu udara ambien. Untuk konsentrasi gas yang melebihi batas yaitu gas $\mathrm{NO}_{2}, \mathrm{SO}_{2}$, dan partikulat pada bulan April 2007 yang mencapai angka $0,0667 \mathrm{ppm}$. Angka tersebut melebihi nilai baku mutu udara ambien yaitu 0,05 ppm (BTKL dan PPM, 2007). Polutan udara tersebut dapat mengakibatkan berbagai macam gangguan kesehatan terutama gangguan pada saluran pernafasan.

Polutan udara yang dapat mengakibatkan gangguan pada saluran pernafasan adalah gas $\mathrm{NO}_{2}$,
$\mathrm{SO}_{2}, \mathrm{H}_{2} \mathrm{~S}$, ozon, dan partikel debu. Polutan tersebut bersifat iritasi pada saluran pernafasan yang dapat mengakibatkan gangguan fungsi paru. $\mathrm{Gas}_{\mathrm{SO}_{2}}$ dapat menimbulkan efek iritasi pada saluran pernafasan bagian atas karena mudah larut dalam air yang mengakibatkan produksi lendir meningkat sehingga terjadi penyempitan pada saluran pernafasan. Nitrogen dioksida bersifat iritan dan radikal. Gas $\mathrm{NO}_{2}$ termasuk salah satu gas utama dalam reaksi kimia di atmosfer karena dapat menghasilkan ozon di lapisan troposfer setelah bereaksi dengan sinar ultraviolet.

Laporan ILO tahun 2005 tentang penyakit paru akibat kerja memperkirakan insiden rata-rata dari penyakit paru akibat kerja adalah sekitar satu kasus per 1000 pekerja setiap tahun. Di antara semua penyakit akibat kerja, $0-30 \%$ adalah penyakit paru. Sebagian besar penyakit paru akibat kerja mempunyai akibat yang serius, lebih dari 3\% kematian akibat penyakit paru kronik di New York adalah berhubungan dengan pekerjaan. Sebagian besar penyakit paru akibat kerja dapat didiagnosis berdasarkan riwayat penyakit, pemeriksaan fisik, foto toraks, uji faal paru menggunakan spirometer, dan pemeriksaan laboratorium (Milos dan Imamkhasani, 2005).

Gangguan faal paru merupakan salah satu jenis gangguan saluran pernafasan dan masih menjadi masalah bagi kesehatan masyarakat. Gangguan paru merupakan faktor pemula dari kemungkinan terjadinya penyakit Infeksi Saluran Pernafasan Akut (ISPA) dan infeksi paru infeksi paru merupakan penyebab kematian nomor tiga setelah penyakit kardiovaskuler dan penyakit ISPA pada semua kelompok umur. Gangguan faal paru juga termasuk penyakit infeksi yang menduduki peringkat pertama penyebab kematian (SKRT, 2001). Penyakit ini menyebabkan kelainan ventilasi berupa gangguan obstruksi saluran pernafasan yang disebabkan oleh bronkitis kronik dan atau emfisema obstruksi saluran pernafasan yang berlangsung progresif dan dapat bersamaan dengan keadaan hiperaktivitas.

Menurut penelitian yang dilakukan Umar (2013), Faktor yang Memengaruhi Kapasitas Paru Peternak Ayam (Studi Pada Peternakan Ayam CV. Malu'oJaya dan Peternakan Ayam Risky Layer Kabupaten Bone Bolango) bahwa tidak ada hubungan jenis kelamin, umur, kebiasaan merokok, kebiasaan olahraga, lama paparan, penggunaan masker dengan kapasitas paru, serta ada hubungan masa kerja dan IMT dengan kapasitas paru. 
Gangguan faal paru tidak hanya disebabkan oleh kadar debu yang tinggi saja, melainkan juga dipengaruhi oleh karakteristik yang terdapat pada individu pekerja seperti umur, jenis kelamin, masa kerja, pemakaian alat pelindung diri, riwayat merokok dan riwayat penyakit. Penjual unggas yang ada di pasar burung merupakan kelompok berisiko tinggi untuk mengalami gangguan faal paru karena terdapat beberapa faktor yang bisa menyebabkan terjadinya gangguan faal paru di lingkungan pasar burung. Oleh karena itu status faal paru dan faktor yang mempengaruhinya pada penjual unggas yang ada di pasar burung penting untuk dikaji lebih lanjut.

Tujuan penelitian ini adalah mengidentifikasi faktor-faktor yang dapat menyebabkan gangguan faal paru pada penjual unggas yang ada di pasar burung kupang, Surabaya.

\section{METODE}

Metode penelitian ini adalah penelitian deskriptif yang menggambarkan keadaan suatu objek. Rancang bangun yang digunakan pada penelitian ini adalah cross sectional yaitu penelitian yang dilakukan pada satu waktu dan pelaksanaannya bersamaan dengan waktu terjadinya masalah yang sedang diteliti. Ditinjau dari sifat penelitian ini termasuk penelitian observasional karena peneliti hanya melakukan pengamatan tanpa memberikan intervensi pada subjek yang diteliti, yaitu penjual unggas di pasar burung kupang Surabaya.

Penelitian ini dilaksanakan pada bulan November - Agustus 2015 di pasar burung kupang Surabaya. Populasi penelitian ini adalah penjual unggas yang terdaftar secara resmi di pasar burung kupang, Surabaya yang berjumlah 200 orang. Besar sampel dalam penelitian ini ditentukan menggunakan teori Gay \& Diehl (1992), perhitungan besar sampel dengan pertimbangan sasaran penelitian bersifat homogen mempunyai karakteristik yang sama, yaitu berjualan di lingkungan yang sama. Sampel minimumnya adalah $10 \%$ dari total populasi yaitu sebanyak 20 penjual unggas yang terdaftar secara resmi di pasar burung kupang, Surabaya. Cara pengambilan sampel pada penelitian ini dengan menggunakan teknik accidental sampling yaitu dipilih secara kebetulan dari semua penjual unggas di pasar burung yang tidak memiliki riwayat penyakit pernafasan dan terdaftar secara resmi di pasar burung kupang, Surabaya. Variabel penelitian ini dibagi menjadi variabel tergantung, variabel bebas dan variabel kontrol. Variabel tergantung yaitu status faal paru. Variabel bebasnya adalah adanya Karekteristik individu yang meliputi umur, status gizi, masa kerja, dan riwayat merokok. Sedangkan variabel kontrolnya adalah jenis kelamin, riwayat merokok dan pemakaian APD.

Sebelum pengambilan data, peneliti menjelaskan secara singkat mengenai penelitian yang akan dilakukan kepada responden. Peneliti juga menjelaskan mengenai perlakuan terhadap responden, manfaat langsung untuk responden, hak dan kewajiban yang dimiliki oleh responden, dan efek samping dari penelitian yang akan dilakukan.

Data yang dikumpulkan dalam penelitian ini berupa data primer dan data sekunder. Cara pengambilan data primer yaitu dengan pengukuran langsung, kuisioner dan wawancara. Sedangkan data sekunder diperoleh dari instansi pemerintah terkait yang sesuai dengan data yang dibutuhkan.

Data yang telah dikumpulkan pada penelitian ini dianalisis secara kuantitatif dengan membandingkan data-data yang diperoleh dari data primer maupun data sekunder ke dalam teori-teori. Analisis dilakukan dengan menggunakan analisis deskriptif, hasil dari analisis akan dituangkan dalam bentuk narasi dan menjadi sebuah informasi. Hasil penelitian disajikan dengan menggunakan tabel distribusi frekuensi, persentase dan tabulasi silang (crosstab).

\section{HASIL}

\section{Status Faal Paru}

Pemeriksaan status faal paru responden di Pasar Burung Kupang Surabaya dengan menggunakan alat spirometri. Hasil pemeriksaan dikatakan normal jika nilai \%FVC Predicted lebih dari sama dengan 80 dan nilai $\% \mathrm{FEV}_{1}$ Predicted lebih dari sama dengan 80 , dan terdapat gangguan restriksi jika nilai $\% \mathrm{FVC}$ Predicted kurang dari 80 serta terdapat gangguan obstruksi jika nilai $\% \mathrm{FEV}_{1}$ Predicted kurang dari 80. Berikut ini merupakan distribusi status faal

Tabel 1. Distribusi Responden Berdasarkan Status Faal Paru di Pasar Burung Kupang Surabaya Tahun 2015

\begin{tabular}{lcc}
\hline Status Faal Paru & Frekuensi (n) & Persentase (\%) \\
\hline Normal & 13 & 65.0 \\
Tidak Normal & 7 & 35.0 \\
\hline Total & 20 & 100.0 \\
\hline
\end{tabular}


paru responden di Pasar Burung Kupang Surabaya sebagai berikut (Tabel 1):

Tabel di atas menunjukkan bahwa sebagian besar responden memiliki status faal paru yang normal sedangkan responden yang memiliki status faal paru tidak normal hanya sebanyak 7 orang dengan rincian 4 responden memiliki gangguan faal paru obstruksi dengan nilai $\% \mathrm{FEV}_{1}$ Predicted di bawah $80 \%$ dan \%FVC Predicted diatas $80 \%$, 1 responden memiliki gangguan faal paru restriksi dengan nilai $\% \mathrm{FEV}_{1}$ Predicted diatas $80 \%$ dan \%FVC Predicted di bawah $80 \%$, dan 2 responden memiliki gangguan faal paru campuran dengan nilai $\% \mathrm{FEV}_{1}$ Predicted di bawah $80 \%$ dan $\% \mathrm{FVC}$ Predicted di bawah $80 \%$.

Tabel 2. Hasil Pemeriksaan Status Faal Paru Responden di Pasar Burung Kupang Surabaya Tahun 2015

\begin{tabular}{lrrrr}
\hline \multicolumn{1}{c}{ Hasil } & Mean & Min & Max & \multicolumn{1}{c}{ SD } \\
\hline$\% \mathrm{FEV}_{1}$ & 83,1 & 68,2 & 92,0 & 7,3 \\
$\% \mathrm{FVC}$ & 101,5 & 77,6 & 117,6 & 12,5 \\
\hline
\end{tabular}

Berdasarkan tabel di atas, jika dilihat ratarata $\% \mathrm{FEV}_{1}$ dan $\% \mathrm{FVC}$ responden masih termasuk dalam kategori normal. Namun jika dilihat dari nilai minimumnya ada responden yang memiliki $\% \mathrm{FEV}_{1}$ dan $\% \mathrm{FVC}$ yang sangat rendah.

\section{Keluhan Subjektif yang Dirasakan Responden}

Keluhan subjektif yang dimaksudkan adalah keluhan yang dirasakan oleh responden selama berjualan unggas di pasar burung kupang, Surabaya.

Gambar diatas menunjukkan bahwa keluhan subjektif yang dirasakan responden berupa sesak nafas, batuk, mata pedih, dan kepala pusing. Hanya $20 \%$ saja yang tidak mengalami keluhan. Keluhan paling banyak yang dialami responden adalah batuk sebesar $80 \%$.

\section{Faktor Eksternal yang Dapat Mempengaruhi Status Faal Paru}

\section{Konsentrasi Sulfur Dioksida ( $\left.\mathrm{SO}_{2}\right)$}

Konsentrasi Sulfur dioksida yang dimaksudkan adalah konsentrasi $\mathrm{SO}_{2}$ di udara yang ada di lingkungan pasar burung kupang, Surabaya yang diukur di tiga titik berbeda dan lama pengukuran masing-masing titik selama satu jam.

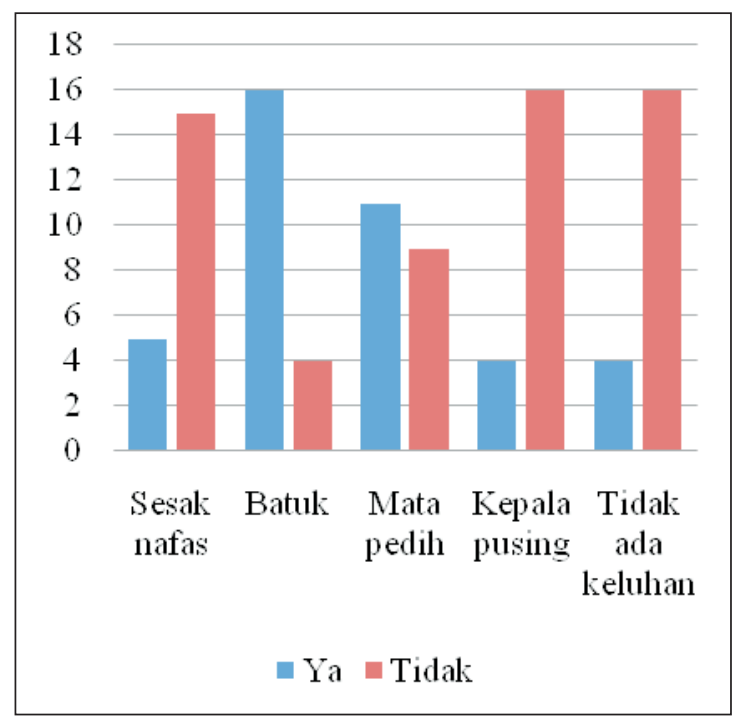

Gambar 1. Frekuensi Keluhan Subjektif yang Dirasakan Responden di Pasar Burung Kupang Surabaya Tahun 2015

Hasil pengukuran konsentrasi $\mathrm{SO}_{2}$ pada titik 1 , 2, dan 3 berturut-turut adalah $0,0042 \mathrm{mg} / \mathrm{m}^{3}, 0,0039$ $\mathrm{mg} / \mathrm{m}^{3}$, dan $0,0061 \mathrm{mg} / \mathrm{m}^{3}$. Kemudian dilakukan rata-rata dari ketiga titik tersebut. Sehingga, didapatkan hasil konsentrasi $\mathrm{SO}_{2}$ di Pasar Burung Kupang Surabaya yaitu $0,0047 \mathrm{mg} / \mathrm{m}^{3}$ dengan suhu udara rata-rata saat pengukuran $33,1^{\circ} \mathrm{C}$ dan kelembaban nisbi 56,7\%. Dalam Peraturan Menteri Tenaga Kerja Dan Transmigrasi Nomor PER.13/ MEN/X/2011 Tahun 2011 tentang nilai ambang batas faktor fisika dan faktor kimia di tempat kerja menyatakan bahwa konsentrasi $\mathrm{SO}_{2}$ yang diperkenankan sebesar $0,25 \mathrm{mg} / \mathrm{m}^{3}$.

\section{Konsentrasi Nitrogen Dioksida ( $\left.\mathrm{NO}_{2}\right)$}

Konsentrasi Nitrogen dioksida yang dimaksudkan adalah konsentrasi $\mathrm{NO}_{2}$ di udara yang ada di lingkungan pasar burung kupang, Surabaya yang diukur di tiga titik berbeda dan lama pengukuran masing-masing titik selama satu jam.

Hasil pengukuran konsentrasi $\mathrm{NO}_{2}$ pada titik 1 , 2, dan 3 berturut-turut adalah 0,0147 ppm, 0,0214 ppm, dan 0,0260 ppm. Kemudian dilakukan ratarata dari ketiga titik tersebut. Sehingga, didapatkan hasil konsentrasi $\mathrm{NO}_{2}$ di Pasar Burung Kupang Surabaya yaitu $0,0207 \mathrm{ppm}$ dengan suhu udara ratarata saat pengukuran $33,1^{\circ} \mathrm{C}$ dan kelembaban nisbi $56,7 \%$. Dalam Peraturan Menteri Tenaga Kerja Dan Transmigrasi Nomor PER.13/MEN/X/2011 Tahun 
2011 tentang nilai ambang batas faktor fisika dan faktor kimia di tempat kerja menyatakan bahwa konsentrasi $\mathrm{NO}_{2}$ yang diperkenankan sebesar 3 ppm.

\section{Konsentrasi Amonia $\left(\mathrm{NH}_{3}\right)$}

Konsentrasi Amonia yang dimaksudkan adalah konsentrasi $\mathrm{NH}_{3}$ di udara yang ada di lingkungan pasar burung kupang, Surabaya yang diukur di tiga titik berbeda dan lama pengukuran masing-masing titik selama satu jam.

Hasil pengukuran konsentrasi $\mathrm{NH}_{3}$ pada titik 1, 2, dan 3 berturut-turut adalah $0.0350 \mathrm{ppm}$, 0,0836 ppm, dan 0,0727 ppm. Kemudian dilakukan hasil rata-rata dari ketiga titik tersebut. Sehingga, didapatkan hasil konsentrasi $\mathrm{NH}_{3}$ di Pasar Burung Kupang Surabaya yaitu 0,0638 ppm dengan suhu udara rata-rata saat pengukuran $33,1^{\circ} \mathrm{C}$ dan kelembaban nisbi 56,7\%. Dalam Peraturan Menteri Tenaga Kerja Dan Transmigrasi Nomor PER.13/ MEN/X/2011 Tahun 2011 tentang nilai ambang batas faktor fisika dan faktor kimia di tempat kerja menyatakan bahwa konsentrasi $\mathrm{NH}_{3}$ yang diperkenankan sebesar $25 \mathrm{ppm}$.

\section{Konsentrasi Hidrogen Sulfida $\left(\mathrm{H}_{2} \mathrm{~S}\right)$}

Konsentrasi Hidrogen sulfida yang dimaksudkan adalah konsentrasi $\mathrm{H}_{2} \mathrm{~S}$ di udara yang ada di lingkungan pasar burung kupang, Surabaya yang diukur di tiga titik berbeda dan lama pengukuran masing-masing titik selama satu jam.

Pengukuran konsentrasi $\mathrm{H}_{2} \mathrm{~S}$ dari ketiga titik didapatkan hasil yang sama yaitu $0,0002 \mathrm{ppm}$, kemudian dilakukan hasil rata-rata dari ketiga titik tersebut. Sehingga, didapatkan hasil konsentrasi $\mathrm{H}_{2} \mathrm{~S}$ di Pasar Burung Kupang Surabaya yaitu 0,0002 ppm dengan suhu udara rata-rata saat pengukuran $33,1^{\circ} \mathrm{C}$ dan kelembaban nisbi 56,7\%. Dalam Peraturan Menteri Tenaga Kerja Dan Transmigrasi Nomor PER.13/MEN/X/2011 Tahun 2011 tentang nilai ambang batas faktor fisika dan faktor kimia di tempat kerja menyatakan bahwa konsentrasi $\mathrm{H}_{2} \mathrm{~S}$ yang diperkenankan sebesar $1 \mathrm{ppm}$.

\section{Kadar Debu}

Kadar debu yang dimaksudkan adalah kadar debu total yang ada di lingkungan pasar burung kupang, Surabaya yang diukur di tiga titik berbeda dan lama pengukuran masing-masing titik selama satu jam.
Hasil pengukuran kadar debu pada titik 1, 2, dan 3 berturut-turut adalah $0,2122 \mathrm{mg} / \mathrm{m}^{3}, 0,3503$ $\mathrm{mg} / \mathrm{m}^{3}$, dan $0,5918 \mathrm{mg} / \mathrm{m}^{3}$. Kemudian dilakukan hasil rata-rata dari ketiga titik tersebut. Sehingga, didapatkan hasil kadar debu di Pasar Burung Kupang Surabaya yaitu $0,3848 \mathrm{mg} / \mathrm{m}^{3}$ dengan suhu udara rata-rata saat pengukuran $33,1^{\circ} \mathrm{C}$ dan kelembaban nisbi 56,7\%. Dalam Peraturan Menteri Tenaga Kerja Dan Transmigrasi Nomor PER.13/MEN/X/2011 Tahun 2011 tentang nilai ambang batas faktor fisika dan faktor kimia di tempat kerja menyatakan bahwa kadar debu atau partikulat tidak terklasifikasi (partikulat inhalable) yang diperkenankan sebesar $10 \mathrm{mg} / \mathrm{m}^{3}$.

\section{Kebersihan Kandang Unggas}

Kebersihan kandang unggas yang dimaksudkan adalah seberapa sering responden membersihkan kandang unggas/kios tempat berjualan di pasar burung kupang Surabaya dalam seminggu.

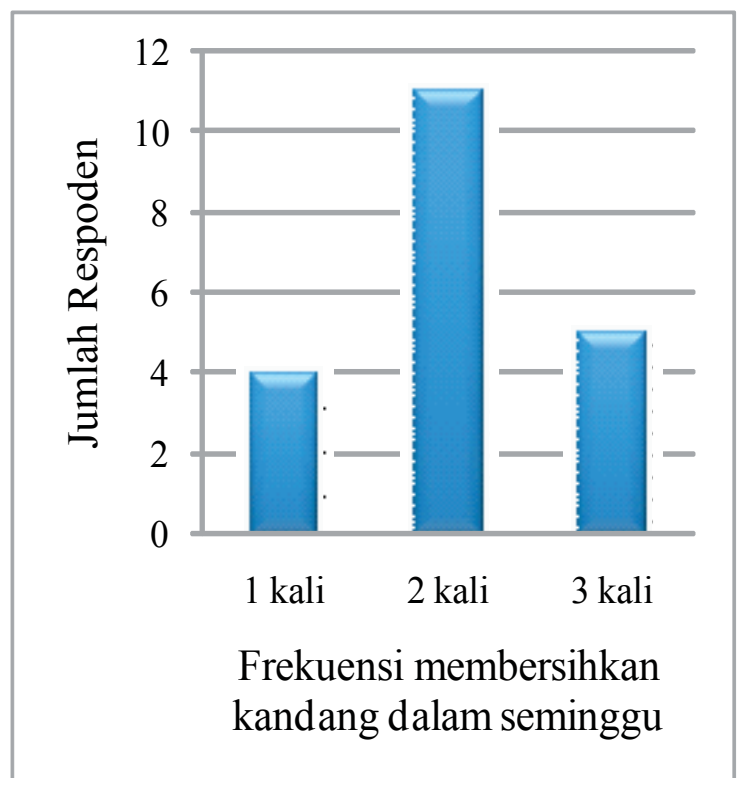

Gambar 2. Frekuensi Responden Membersihkan Kandang Unggas dalam Seminggu di Pasar Burung Kupang Surabaya Tahun 2015

Gambar di atas menunjukkan bahwa sebagian besar responden membersihkan kandang unggas hanya dua kali dalam seminggu dan itu dilakukan dengan selang waktu tiga hari sekali. Sedangkan responden yang membersihkan kandang unggas tiga kali dalam seminggu selang waktunya adalah tiap dua hari sekali. 
Faktor Internal yang Dapat Memengaruhi Status Faal Paru

\section{Umur}

Umur yang dimaksudkan adalah Usia responden terhitung sejak lahir hingga penelitian berlangsung dan dibedakan menjadi: 20-29 tahun, 30-39 tahun, 40-49 tahun, 50-59 tahun, dan 60-69 tahun.

Berdasarkan tabel 11 bahwa responden paling banyak berada pada kelompok umur dengan rentang 30 tahun sampai dengan 39 tahun yaitu sebanyak 6 responden (30\%). Rata-rata umur responden di Pasar Burung Kupang adalah 39,2 \pm 12,77 tahun dengan umur responden terendah 22 tahun dan tertinggi 66 tahun.

Tabel 3. Distribusi Frekuensi Status Faal Paru Berdasarkan Umur Responden di Pasar Burung Kupang Surabaya Tahun 2015

\begin{tabular}{lcccccc}
\hline \multirow{2}{*}{ Umur (tahun) } & \multicolumn{3}{c}{ Status Faal Paru } & \multirow{2}{*}{ Total } \\
\cline { 2 - 6 } & \multicolumn{3}{c}{ Normal } & \multicolumn{2}{c}{ Tidak } \\
Normal & & \\
\cline { 2 - 6 } & $\mathbf{n}$ & $\%$ & $\mathbf{n}$ & $\mathbf{\%}$ & $\mathbf{n}$ & $\mathbf{\%}$ \\
\hline $20-29$ & 5 & 100 & 0 & 0 & 5 & 100 \\
$30-39$ & 3 & 50 & 3 & 50 & 6 & 100 \\
$40-49$ & 3 & 60 & 2 & 40 & 5 & 100 \\
$50-59$ & 1 & 50 & 1 & 50 & 2 & 100 \\
$60-69$ & 1 & 50 & 1 & 50 & 2 & 100 \\
\hline
\end{tabular}

Median dari umur responden adalah 35 tahun dengan modus umur responden adalah 33 tahun. Rata-rata umur responden yang mengalami gangguan faal paru adalah 43,4 $\pm 11,41$ tahun sedangkan responden yang memiliki faal paru normal adalah $36,9 \pm 13,30$ tahun.

\section{Status Gizi}

Status gizi yang dimaksudkan adalah Kondisi tubuh seseorang akibat mengonsumsi makanan dan zat gizi. Status gizi digambarkan dengan Indeks Masa Tubuh (WHO, 2003) yaitu: kurus (IMT < 18,5), normal (IMT 18,5-24,9), dan gemuk (IMT $>25$ ).

Berdasarkan tabel di atas responden yang memiliki IMT dengan kategori normal dan gemuk jumlahnya hampir sama, sedangkan tidak responden yang memiliki IMT dengan kategori kurus. Persentase responden yang mengalami gangguan faal paru pada kategori normal lebih besar daripada kategori gemuk.
Tabel 4. Distribusi Frekuensi Status Faal Paru Berdasarkan Indeks Masa Tubuh Responden di Pasar Burung Kupang Surabaya Tahun 2015

\begin{tabular}{lcccccc}
\hline \multirow{1}{*}{ IMT } & \multicolumn{3}{c}{ Status Faal Paru } & \multirow{2}{*}{ Total } \\
\cline { 2 - 5 } & \multicolumn{2}{c}{ Normal } & \multicolumn{2}{c}{$\begin{array}{c}\text { Tidak } \\
\text { Normal }\end{array}$} & & \\
\cline { 2 - 6 } & $\mathbf{n}$ & $\mathbf{\%}$ & $\mathbf{n}$ & $\mathbf{\%}$ & $\mathbf{N}$ & $\mathbf{\%}$ \\
\hline Kurus & 0 & 0 & 0 & 0 & 0 & 0 \\
Normal & 7 & 63,6 & 4 & 36,4 & 11 & 100 \\
Gemuk & 6 & 66,7 & 3 & 33,3 & 9 & 100 \\
\hline
\end{tabular}

\section{Masa Kerja}

Masa kerja yang dimaksudkan adalah lama kerja responden (penjual unggas) mulai dari awal berjualan unggas hingga penelitian berlangsung yang dibedakan menjadi 1-10 tahun, 11-20 tahun, 21-30 tahun dan 31-40 tahun.

Berdasarkan tabel 5, responden paling banyak berada pada masa kerja dengan rentan 1 sampai 10 tahun. Rata-rata masa kerja responden adalah 15,8 \pm 11,17 tahun dengan masa kerja responden minimal 1 tahun dan masa kerja responden maksimal 40 tahun. Lama kerja semua responden sama yaitu 12 jam/ hari. Median dan modus dari masa kerja responden adalah 15 tahun.

Tabel 5. Distribusi Frekuensi Status Faal Paru Berdasarkan Masa Kerja Responden di Pasar Burung Kupang Surabaya Tahun 2015

\begin{tabular}{|c|c|c|c|c|c|c|}
\hline \multirow{3}{*}{$\begin{array}{c}\text { Masa Kerja } \\
\text { (tahun) }\end{array}$} & \multicolumn{4}{|c|}{ Status Faal Paru } & \multirow{2}{*}{\multicolumn{2}{|c|}{ Total }} \\
\hline & \multicolumn{2}{|c|}{ Normal } & \multicolumn{2}{|c|}{$\begin{array}{c}\text { Tidak } \\
\text { Normal }\end{array}$} & & \\
\hline & $\mathbf{n}$ & $\%$ & $\mathbf{n}$ & $\%$ & $\mathbf{n}$ & $\%$ \\
\hline $1-10$ & 8 & 100 & 0 & 0 & 8 & 100 \\
\hline $11-20$ & 3 & 42,8 & 4 & 57,2 & 7 & 100 \\
\hline $21-30$ & 1 & 33,3 & 2 & 66,7 & 3 & 100 \\
\hline $31-40$ & 1 & 50 & 1 & 50 & 2 & 100 \\
\hline
\end{tabular}

Rata-rata masa kerja responden yang mengalami gangguan faal paru adalah 24,16 \pm 9,70 tahun sedangkan yang memiliki faal paru normal adalah $11,61 \pm 10,13$ tahun.

\section{Riwayat Merokok}

Riwayat merokok yang dimaksudkan adalah Kebiasaan menghisap rokok yang dilakukan oleh responden setiap hari. 
Tabel 6. Distribusi Frekuensi Status Faal Paru Berdasarkan Status Merokok Responden di Pasar Burung Kupang Surabaya Tahun 2015

\begin{tabular}{|c|c|c|c|c|c|c|}
\hline \multirow{3}{*}{ Merokok } & \multicolumn{4}{|c|}{ Status Faal Paru } & \multirow{2}{*}{\multicolumn{2}{|c|}{ Total }} \\
\hline & \multicolumn{2}{|c|}{ Normal } & \multicolumn{2}{|c|}{$\begin{array}{c}\text { Tidak } \\
\text { Normal }\end{array}$} & & \\
\hline & $\mathbf{n}$ & $\%$ & $\mathbf{n}$ & $\%$ & $\mathbf{n}$ & $\%$ \\
\hline Ya & 11 & 68,8 & 5 & 31,2 & 16 & 100 \\
\hline Tidak & 2 & 50 & 2 & 50 & 4 & 100 \\
\hline
\end{tabular}

Berdasarkan tabel di atas sebagian besar responden adalah perokok. Rata-rata rokok yang dikonsumsi responden yang mengalami gangguan faal adalah sebanyak 17,2 $\pm 3,03$ batang/hari sedangkan yang memiliki faal paru normal adalah $15,5 \pm 2,97$ batang/hari dan rata-rata lama merokok responden yang mengalami gangguan faal adalah $14,6 \pm 4,56$ tahun sedangkan yang memiliki faal paru normal adalah 14,4 \pm 7,25 tahun. Dosis rokok yang dikonsumsi didapatkan dari hasil perkalian jumlah rokok yang dikonsumsi perhari dengan lama merokok dalam tahun sehingga satuan yang digunakan adalah batang tahun.

Tabel 7. Distribusi Frekuensi Status Faal Paru Berdasarkan Dosis Rokok Responden di Pasar Burung Kupang Surabaya Tahun 2015

\begin{tabular}{|c|c|c|c|c|c|c|}
\hline \multirow{3}{*}{$\begin{array}{c}\text { Dosis Rokok } \\
\text { (batang tahun) }\end{array}$} & \multicolumn{4}{|c|}{ Status Faal Paru } & \multirow{2}{*}{\multicolumn{2}{|c|}{ Total }} \\
\hline & \multicolumn{2}{|c|}{ Normal } & \multicolumn{2}{|c|}{$\begin{array}{c}\text { Tidak } \\
\text { Normal }\end{array}$} & & \\
\hline & $\mathbf{n}$ & $\%$ & $\mathbf{n}$ & $\%$ & $\mathbf{n}$ & $\%$ \\
\hline$\leq 200$ & 6 & 85,7 & 1 & 14,3 & 7 & 100 \\
\hline$>200$ & 5 & 55,6 & 4 & 44,4 & 9 & 100 \\
\hline
\end{tabular}

Berdasarkan tabel di atas rata-rata dosis rokok responden yang mengalami gangguan faal adalah $263,6 \pm 56,61$ batang tahun sedangkan yang memiliki faal paru normal adalah $212,4 \pm 121,71$ batang tahun.

\section{PEMBAHASAN}

\section{Status Faal Paru Responden}

Hasil pemeriksaan faal paru menunjukkan bahwa dari 20 responden, terdapat 13 (65\%) responden memiliki status fungsi paru normal dan $7(35 \%)$ responden mengalami gangguan faal paru dengan rincian $4(20 \%)$ responden mengalami gangguan faal paru obstruksi ringan, 1 (5\%) responden mengalami gangguan faal paru restriksi ringan, dan $2(10 \%)$ responden mengalami gangguan faal paru campuran. Dapat dikatakan hampir setengah dari total responden yang ada di Pasar Burung Kupang Surabaya mengalami gangguan faal paru. Gangguan faal paru yang banyak dialami oleh responden di Pasar Burung Kupang Surabaya berupa obstruksi. Obstruksi merupakan gangguan saluran nafas baik struktural (anatomis) maupun fungsional yang menyebabkan perlambatan aliran udara respirasi. Kelainan obstruksi dapat dijumpai pada kelainan intra luminer (lumen bronkus normal tetapi ada massa dalam lumen tersebut yang dapat berupa tumor maupun benda asing) atau karena menebalnya lumen bronkus seperti pada perokok, penderita asma, dan penderita bronkitis kronis.

Pemeriksaan faal paru pada responden meliputi pemeriksaan FEV1 dan FVC. Forced Expiratory Volume (FEV1) adalah volume gas yang dikeluarkan dalam satu detik melalui ekspirasi paksa sesudah inspirasi penuh. Forced Vital Capacity (FVC) adalah volume total gas yang dapat dikeluarkan setelah inspirasi penuh secara paksa. FEV1 dan FVC merupakan pemeriksaan sederhana yang sering kali informatif, abnormal pada banyak penderita penyakit paru dan sering kali bermakna dalam menilai progress penyakit (West, 2010). Nilai ratarata \%FEV1 responden yang ada di Pasar Burung Kupang Surabaya sebesar 83,09 dan rata-rata \%FVC nya sebesar 101,49 . Nilai rata-rata $\%$ FEV 1 dan $\% \mathrm{FVC}$ responden termasuk dalam kategori normal, namun nilai rata-rata \%FEV1 sangat mendekati batas minimal yang sudah ditentukan yaitu kurang dari 80. Dapat dikatakan bahwa responden yang ada di Pasar Burung Kupang Surabaya rentan mengalami gangguan faal paru obstruksi.

Timbulnya gangguan faal paru pada pekerja dapat dipengaruhi oleh berbagai faktor, baik faktor internal maupun faktor eksternal, yang dalam jangka waktu panjang dapat menimbulkan beberapa penyakit paru yang sesuai dengan kondisi paru nantinya. Beberapa penyakit paru yang dapat muncul di pasar burung antara lain Penyakit Paru Obstruktif Kronis (PPOK) berupa emfisema, bronkitis kronis, alveolitis allergika dan asma kerja.

\section{Faktor Eksternal yang dapat Memengaruhi Status Faal Paru}

Pengukuran konsentrasi gas iritan dan kadar debu di Pasar Burung Kupang Surabaya dilakukan di tiga titik. Karena bentuk pasar burung yang memanjang di sepanjang jalan maka titik pengukuran 
disesuaikan agar hasil yang diperoleh dapat mewakili seluruh tempat di Pasar Burung Kupang Surabaya. Pengukuran dilakukan pada 3 titik berbeda yang masing-masing dilakukan selama 1 jam. Pengukuran pertama dilakukan di titik 1 yang berada pada area depan/parkir Pasar Burung Kupang Surabaya pada pukul 11.45 WIB - 12.45 WIB. Pengukuran kedua dilakukan di titik 2 yang berada pada area tengah Pasar Burung Kupang Surabaya pada pukul 12.55 WIB - 13.55 WIB. Pengukuran ketiga dilakukan di titik 3 yang berada pada area ujung Pasar Burung Kupang Surabaya pada pukul 14.05 WIB - 15.05 WIB. Lokasi yang dipilih sebagai titik pengukuran merupakan lokasi tempat berkumpulnya banyak penjual unggas sehari-sehari.

Gas yang diukur di Pasar Burung Kupang Surabaya terdiri dari 4 macam, yaitu: Sulfur dioksida $\left(\mathrm{SO}_{2}\right)$, Nitrogen dioksida $\left(\mathrm{NO}_{2}\right)$, Amonia $\left(\mathrm{NH}_{3}\right)$, dan Hidrogen sulfida $\left(\mathrm{H}_{2} \mathrm{~S}\right)$. Semuanya termasuk dalam jenis gas yang bersifat iritan dengan tingkat kelarutan dalam air yang berbeda-beda, mulai dari yang tingkat kelarutannya rendah, sedang, sampai yang tingkat kelarutannya tinggi. Sumber dari gas tersebut berasal dari emisi gas buang kendaraan bermotor yang lalu lalang di pasar burung dan juga berasal dari kotoran unggas yang dijual. Penelitian yang dilakukan oleh Nurbiantara (2010), tentang Pengaruh Polusi Udara Terhadap Fungsi Paru Pada Polisi Lalu Lintas di Surakarta mendapatkan hasil bahwa pengaruh konsentrasi gas Sulfur dioksida $\left(\mathrm{SO}_{2}\right)$, Nitrogen dioksida $\left(\mathrm{NO}_{2}\right)$, Amonia $\left(\mathrm{NH}_{3}\right)$, dan Hidrogen sulfida $\left(\mathrm{H}_{2} \mathrm{~S}\right)$ terhadap fungsi paru adalah signifikan.

Hasil dari pengukuran konsentrasi gas iritan dan kadar debu memang semuanya masih jauh di bawah NAB, namun jika dibandingkan dengan hasil penelitian yang dilakukan oleh Sari (2011), tentang kualitas udara ambien di Terminal Joyoboyo Surabaya konsentrasi gas Sulfur dioksida $\left(\mathrm{SO}_{2}\right)$, Nitrogen dioksida $\left(\mathrm{NO}_{2}\right)$, Amonia $\left(\mathrm{NH}_{3}\right)$, dan Hidrogen sulfida $\left(\mathrm{H}_{2} \mathrm{~S}\right)$ dan kadar debu di sana masih lebih rendah daripada di pasar burung kupang Surabaya. Hal itu tentu tidak bisa diabaikan begitu saja, juga adanya keluhan-keluhan yang dialami responden tidak bisa dibiarkan begitu saja. Keluhan berupa sesak nafas, batuk, dan mata pedih sangat mungkin itu semua disebabkan oleh paparan debu organik yang berasal dari kotoran unggas dan gas iritan yang ada di lingkungan Pasar Burung Kupang Surabaya. Didukung dengan fakta bahwa sebagian besar responden hanya membersihkan kandang unggas dua kali dalam seminggu dengan selang waktu tiga hari sekali. Hal ini tentu membuat responden terpapar lebih lama oleh kotoran unggas yang menumpuk dan tidak dibersihkan setiap hari.

Bahaya dari gas yang bersifat iritan ini apabila terhirup ke dalam saluran pernafasan dengan konsentrasi yang melebihi Nilai Ambang Batas (NAB) yang telah ditentukan atau terpapar secara terus menerus dalam jangka waktu yang lama dapat menyebabkan iritasi pada saluran pernafasan dan mengakibatkan gangguan faal paru berupa obstruksi.

\section{Faktor Internal yang dapat Memengaruhi Status Faal Paru}

Selain dari faktor eksternal status faal paru juga sangat dipengaruhi oleh faktor internal. Karakteristik individu responden meliputi umur, jenis kelamin, masa kerja, status gizi, riwayat merokok, pemakaian alat pelindung diri, dan riwayat penyakit. Pada penelitian ini jenis kelamin, pemakaian alat pelindung diri, dan riwayat penyakit termasuk dalam variabel kontrol. Total 20 responden yang dipilih semuanya berjenis kelamin laki-laki, karena mayoritas penjual unggas di Pasar Burung Kupang Surabaya adalah laki-laki dan tidak ada penjual unggas di Pasar Burung Kupang Surabaya yang memakai alat pelindung diri pada saat berjualan. Tujuan dari penelitian ini adalah untuk menggambarkan status faal paru penjual unggas, oleh karena itu responden yang dipilih harus tidak pernah memiliki riwayat penyakit yang berhubungan dengan saluran pernafasan.

Dari hasil penelitian didapatkan bahwa distribusi umur responden di Pasar Burung Kupang Surabaya sangat beragam mulai dari umur 22 tahun sampai dengan 66 tahun. Pada rentang umur 2029 tahun tidak ada responden yang mengalami gangguan faal paru. Hal ini karena Individu normal mengalami perubahan (nilai) fungsi paru secara fisiologis sesuai dengan perkembangan usia dan pertumbuhan parunya (lung growth). Dimulai pada fase anak sampai sekitar usia 22-24 tahun, terjadi pertumbuhan paru yang menjadikan nilai fungsi paru semakin besar seiring dengan pertambahan usia. Beberapa waktu nilai fungsi paru menetap (stasioner) kemudian menurun secara gradual (pelanpelan), sekitar pada usia 30 tahun sudah mulai terjadi penurunan, selanjutnya nilai fungsi paru $(\mathrm{KVP}=$ Kapasitas Vital Paksa dan FEV1 = Volume Ekspirasi Paksa Satu Detik Pertama) mengalami penurunan rerata sekitar $20 \mathrm{ml}$ tiap pertambahan satu tahun usia individu (West, 2010). Sedangkan 
Responden yang mengalami gangguan faal paru paling banyak berada pada rentang umur 30 tahun sampai dengan 39 tahun. Pada rentang-rentang umur berikutnya persentase responden yang mengalami gangguan faal paru sebesar 50\% atau setengah dari jumlah responden yang berada pada rentang umur tersebut. Dapat dilihat juga dari rata-rata umur responden yang mengalami gangguan faal paru adalah $43,4 \pm 11,41$ tahun sedangkan yang memiliki faal paru normal adalah $36,9 \pm 13,30$ tahun. Hal ini menunjukkan bahwa Faktor yang mempengaruhi kapasitas fungsi paru diantaranya adalah proses penuaan atau bertambahnya umur.

Menurunnya kekuatan dan daya tahan otot respirasi dapat diakibatkan oleh karena malnutrisi dan penurunan berat badan. Status gizi yang buruk akan menyebabkan daya tahan tubuh menurun dan menurunnya daya tahan tubuh akan mengakibatkan mudah terserang mikroba. Status gizi responden ditentukan dari nilai Indeks Masa Tubuh (IMT) yang dibagi menjadi 3 kategori: kurus, normal, dan gemuk. Tidak ada responden yang termasuk dalam kategori kurus. Sebanyak 11 (55\%) responden termasuk dalam kategori normal dengan 4 responden mengalami gangguan faal paru dan 9 (45\%) responden dalam kategori gemuk dengan 3 responden mengalami gangguan faal paru. Hal ini menunjukkan bahwa hampir tidak ada beda antara responden yang memiliki IMT normal dengan responden yang memiliki IMT gemuk. Hasil penelitian yang dilakukan oleh Damayanti dkk (2007), dan Munawar (2014), menyatakan bahwa status gizi tidak mempengaruhi faal paru.

Masa kerja menentukan lama paparan seseorang terhadap debu yang dapat mengakibatkan gangguan fungsi paru. Semakin lama paparan (masa kerja) semakin besar kemungkinan seseorang mendapatkan risiko tersebut. Salah satu variabel potensial yang dapat menimbulkan gangguan fungsi paru adalah lamanya seseorang terpapar debu organik. Masa kerja responden di Pasar Burung Kupang Surabaya paling banyak berada pada rentang waktu 1-10 tahun yaitu sebesar $40 \%$. Namun semua responden yang berada pada rentang tersebut tidak ada yang mengalami gangguan faal paru. Sedangkan pada masa kerja responden pada rentang-rentang waktu berikutnya responden yang mengalami gangguan faal paru persentasenya lebih dari sama dengan 50\%. Bila dilihat dari rata-rata masa kerja responden yang mengalami gangguan faal paru adalah 24,16 $\pm 9,70$ tahun sedangkan yang memiliki faal paru normal adalah $11,61 \pm 10,13$ tahun. Hal ini menunjukkan semakin lama seseorang bekerja pada tempat yang mengandung debu akan makin tinggi risiko terkena gangguan kesehatan, terutama gangguan saluran pernafasan (Suma'mur, 2009). Hasil penelitian Nugraheni (2004), juga menyatakan bahwa masa kerja mempengaruhi kejadian gangguan fungsi paru.

Kebiasaan merokok dapat menyebabkan perubahan struktur dan fungsi saluran nafas serta jaringan paru. Akibat perubahan anatomi saluran nafas pada perokok akan menimbulkan penurunan pada fungsi paru (Muis dkk, 2008). Mayoritas responden yang ada di Pasar Burung Kupang Surabaya adalah perokok. 16 dari 20 atau sebanyak $80 \%$ responden menyatakan bahwa mereka merokok dan $31,2 \%$ diantaranya mengalami gangguan faal paru. Dari 4 responden yang tidak merokok, 2 diantaranya mengalami gangguan faal paru. Namun 2 responden tersebut memiliki masing-masing umur 50 dan 64 tahun serta masa kerja 25 dan 40 tahun. Jadi walaupun responden tersebut tidak merokok, tetap sangat mungkin mengalami gangguan faal paru.

Riwayat merokok selalu berkaitan dengan dua hal yaitu, jumlah konsumsi rokok/hari dan berapa lama telah merokok. Hanya 2 responden yang mengonsumsi rokok $\leq 12$ batang/hari dan keduanya tidak ada yang mengalami gangguan faal paru. Sedangkan sisanya mengonsumsi rokok $>12$ batang/ hari, 5 diantaranya mengalami gangguan faal paru. Berdasarkan lama merokok dari total responden yang merokok $\leq 10$ tahun hanya 1 responden yang mengalami gangguan faal paru dan dari total responden yang merokok $>10$ tahun sebanyak 4 $(44,4 \%)$ responden mengalami gangguan faal paru. Jika jumlah konsumsi rokok dan lama merokok dikalikan maka didapatkan dosis rokok responden. Responden dengan dosis rokok $>200$ batang tahun lebih banyak yang mengalami gangguan faal paru daripada yang responden dengan dosis rokok $\leq 200$ batang tahun. Hal ini menunjukkan semakin banyak jumlah rokok yang dikonsumsi responden semakin rentan mengalami gangguan faal paru. Gangguan kondisi faal paru yaitu obstruksi dan restriksi dipengaruhi karena beberapa hal, diantaranya adalah merokok. Rokok yang dihisap mengandung senyawa-senyawa yang dapat mengendap dalam paru seperti nikotin. Endapan senyawa-senyawa tersebut semakin lama semakin banyak dan dapat mempersempit jalur udara untuk keluar dan masuk, sehingga dapat mempengaruhi fisiologi paru seseorang (West, 2010). 


\section{SIMPULAN}

Sepertiga dari total responden di Pasar Burung Kupang Surabaya mengalami gangguan faal paru. Gangguan faal paru tersebut berupa obstruksi ringan, restriksi ringan dan juga campuran.

Konsentrasi gas iritan Sulfur dioksida $\left(\mathrm{SO}_{2}\right)$, Nitrogen dioksida $\left(\mathrm{NO}_{2}\right)$, Amonia $\left(\mathrm{NH}_{3}\right)$, dan Hidrogen sulfida $\left(\mathrm{H}_{2} \mathrm{~S}\right)$ dan kadar debu di Pasar Burung Kupang Surabaya menunjukkan angka di bawah Nilai Ambang Batas (NAB) menurut Permenakertrans No.13/MEN/X/2011 Tahun 2011, baik konsentrasi pengukuran ketiga titik maupun hasil rata-rata pengukuran. $\mathrm{NH}_{3}$ memiliki konsentrasi yang paling tinggi. Umur, masa kerja dan riwayat merokok tampaknya memiliki kecenderungan terhadap status faal paru penjual unggas di pasar burung Kupang Surabaya.

Berdasarkan hasil pengukuran didapatkan konsentrasi gas iritan dan kadar debu di Pasar Burung Kupang Surabaya masih di bawah NAB. Namun, konsentrasi $\mathrm{NH}_{3}$ menunjukkan yang paling tinggi dan debu organik yang berasal dari kotoran unggas memiliki sifat alergen serta jumlah responden yang mengalami gangguan faal paru di Pasar Burung Kupang Surabaya cukup banyak. Pekerja diharapkan dapat mengurangi paparan debu organik dan $\mathrm{NH}_{3}$ yang berasal dari kotoran unggas dengan cara menjaga kebersihan kandang dan kios jualan serta membersihkannya secara berkala, menjaga kesehatan fungsi paru dengan mengurangi konsumsi rokok dan untuk upaya preventif diharapkan melakukan pemeriksaan secara berkala ke pelayanan kesehatan terdekat baik puskesmas, rumah sakit atau pun klinik dokter.

\section{DAFTAR PUSTAKA}

Amin, M. 1996. Penyakit Paru Obstruktif Menahun: Polusi Udara, Rokok dan Alfa-1-antitripsin. Cetakan pertama. Airlangga University Press. Surabaya.

Arganata, F.Z. 2015. Status Faal Paru dan Faktor yang Mempengaruhinya pada Penjual Unggas di Pasar Burung Kupang Surabaya. Skripsi. Fakultas Kesehatan Masyarakat Unair: Surabaya.

Balai Besar Teknik Kesehatan Lingkungan dan Pemberantasan Penyakit Menular (BBTKL dan PPM). 2007. Data Pengukuran Kualitas Udara di Kota Surabaya Tahun 2006-2007. Surabaya: Direktorat Jenderal Pengendalian Penyakit dan Penyehatan Lingkungan.
Damayanti T., Yunus. F., Ikhsan M., Sutjahyo K. 2007. Hubungan Penggunaan Masker dengan Gambaran Klinis, Faal Paru dan Foto Toraks Pekerja Terpajan Debu Semen. Majalah Kedokteran Indonesia. Volume: 57, Nomor: 9, September 2007.

Gay, L.R., Diehl, P.L. 1992. Research Methods for Business and Management. Mac Milan Publishing Company. New York.

Kemenakertrans RI. 2011. Permenakertrans No. 13/MEN/X/2011 Tentang Nilai Ambang Batas Faktor Fisika dan Faktor Kimia di Tempat Kerja. Jakarta.

Milos, N., Imamkhasani, S. 2005. Fundamental of Chemical Safety and Major Hazard Control. Jakarta.

Muis M., Syamsiar R., dan Arifah R. 2008. Studi Kapasitas Paru pada Karyawan Departemen Produksi Semen PT. Semen Tonasa Pangkep. Jurnal MKMI. Vol. 4 (No. 1): hal. 41.

Mukono, H.J. 1997. Pencemaran Udara dan Pengaruhnya terhadap Gangguan Saluran Pernapasan. Airlangga University Press. Surabaya.

Munawar, S. 2014. Analisis Pengaruh Paparan Debu Kayu terhadap Faal Paru. Tesis: Fakultas Kesehatan Masyarakat Universitas Airlangga.

Nugraheni, S. 2004. Analisis Faktor Risiko Kadar Debu Organik di Udara terhadap Gangguan Fungsi Paru pada Pekerja Industri Penggilingan Padi di Kab. Demak. Tesis: Universitas Diponegoro.

Nurbiantara, S. 2010. Pengaruh Polusi Udara Terhadap Fungsi Paru Pada Polisi Lalu Lintas di Surakarta. Skripsi: Fakultas Kedokteran UNS. Surakarta.

Sari, N.E. 2011. Kualitas Udara Ambien Di Terminal Joyoboyo. Jurnal. Kesehatan Masyarakat Universitas Airlangga

Survei Kesehatan Rumah Tangga (SKRT). 2001. Pola Penyebab Kematian di Indonesia. Badan Penelitian dan Pengembangan Departemen Kesehatan Republik Indonesia. Jakarta

Suma'mur. 2009. Higiene Perusahaan dan Kesehatan Kerja (Hiperkes). Sagung Seto. Jakarta.

Umar, H. 2013. Faktor yang Memengaruhi Kapasitas Paru Peternak Ayam (Studi Pada Peternakan Ayam CV. Maluo Jaya Dan Peternakan Ayam Rizky Layer Kabupaten Bone Bolango). Skripsi. Fakultas Ilmu Kesehatan Dan Keolahragaan. Universitas Negeri Gorontalo.

West, J. 2010. Patofisiologi Paru Esensial. EGC. Jakarta. 